\title{
KECERNAAN ENERGI, PROTEIN, DAN MINERAL KALSIUM DAN FOSFOR KUDA PACU MINAHASA YANG DIBERI PAKAN LOKAL DAN IMPOR
}

\author{
Inggrit Shinta Mende*, Y.L.R. Tulung**, J. F. Umboh**, W.B. Kaunang** \\ Fakultas Peternakan Universitas Sam Ratulangi Manado, 95115
}

\begin{abstract}
ABSTRAK
Penelitian ini dilakukan untuk mengetahui kemampuan ternak kuda pacu dalam mencerna pakan baik pakan lokal dan impor yang sering digunakan peternak kuda pacu di Minahasa. Kecernaan zat-zat makanan merupakan faktor yang sangat menentukan kualitas bahan pakan atau ransum yang dikonsumsi ternak kuda. Oleh karena itu perlu dilakukan penelitian untuk menguji kecernaan pakan karena tinggi rendahnya kecernaan bahan pakan memberikan arti seberapa besar bahan pakan itu mengandung zat-zat makanan dalam bentuk yang dapat dicernakan ke dalam saluran pencernaan. Penelitian ini menggunakan metode survei. Teknik pengambilan data adalah wawancara dan pengamatan langsung pada lokasi-lokasi peternakan kuda pacu. Data yang dikumpulkan yakni jenis dan jumlah pakan (hijauan dan konsentrat) yang diberikan pada ternak kuda pacu serta jumlah feses (g.ekor ${ }^{-1} \cdot$ hari $^{-1}$ ), kemudian diambil sebanyak 30 sampel masing-masing 15 ekor kuda pacu yang menggunakan pakan lokal dan 15 ekor kuda pacu yang menggunakan pakan impor. Data hasil penelitian dianalisis statistik dengan menggunakan uji $\mathrm{t}$ ( $\mathrm{t}$ test). Hasil uji $\mathrm{t}$, menunjukan bahwa kecernaan energi, protein dan mineral kalsium $(\mathrm{Ca})$ dan fosfor $(\mathrm{P})$ pakan impor berbeda nyata lebih tinggi $(\mathrm{P}<0,05)$ dibandingkan dengan pakan lokal.
\end{abstract}

\footnotetext{
*) Alumni

**) Jurusan Ilmu Nutrisi dan Makanan Ternak
}

Berdasarkan hasil penelitian ini dapat disimpulkan bahwa kecernaan energi, protein dan mineral kalsium (Ca) dan Fosfor (P) untuk pakan impor lebih baik dibandingkan dengan pakan lokal.
Kata kunci: Kecernaan Energi, Protein, Mineral Kalsium ( $\mathrm{Ca}$ ) dan Fosfor (P), Kuda Pacu, Pakan Lokal, Pakan Impor.

\section{ABSTRACT}

ENERGY, PROTEIN, AND
MINERAL CALCIUM AND
PHOSPHORUS DIGESTIBILITY OF
RACE HORSES CONSUMED LOCAL
AND IMPORTED FEEDSTUFFS. An
experiment was conducted to determine the ability of race horse in digesting either local or imported feedstuffs used mostly by race horse owner in Minahasa. The digestibility of nutrients is a determinant factor in feedstuffs or diet quality consumed by horses. Therefore, a study on determining the digestibility of feedstuffs is really needed because the rate of digestibility can be used as an indicator of how much nutrients in feedstuffs can be digested in the gastrointestinal tract. The present study was conducted using survey method. Data was collected using interview and direct observation on the race horses farmer's location. Data collected was: type and amount of diets (forage and concentrate) given to the horses, and amount of faeces (g.head ${ }^{-1}$.day ${ }^{-}$ ${ }^{1}$ ), and 30 samples, 15 horses each using local feedstuffs, and 15 samples (horses) using imported feedstuffs. 
Data was statistically analyzed using t test. Research results showed that energy, protein, calcium, and phosphorus digestibility of imported feedstuffs significantly higher $(P<0,05)$ than local feedstuffs. It can be concluded that digestibility of imported feedstuffs is still better than local feedstuffs.

Keywords: Digestibility, Energy, Protein, Calcium (Ca), Phosphorus (P), Race Horses, Imported Feedstuffs, Local Feedstuffs.

\section{PENDAHULUAN}

Kuda pacu yang ada di Indonesia umumnya merupakan jenis kuda poni yang bertubuh kecil. Umumnya postur kudakuda tersebut masih jauh dari standar untuk digunakan sebagai kuda olahraga apalagi untuk pacuan (Izaak, 1985 disitasi Oroh, 2004). Kuda-kuda yang diperlombakan di berbagai negara yakni dari jenis Thoroughbred satu-satunya jenis kuda yang dipakai secara internasional sebagai kuda pacu (Blakely dan Blade, 1992). Usaha untuk memperbaiki mutu ternak kuda pacu Indonesia muncul setelah peternak mengusulkan kepada Pordasi (Persatuan Olahraga Berkuda Seluruh Indonesia) pada tahun 1974, sehingga didatangkan pejantan Thoroughbred dan disilangkan dengan kuda poni lokal.

Kuda, sapi, maupun kerbau adalah jenis ternak dengan tujuan produksi yang berbeda, di mana ternak sapi dan kerbau selain sebagai ternak kerja juga dimanfaatkan sebagai sumber daging, sedangkan ternak kuda tujuan produksi yang dikenal selama ini adalah untuk kemampuan kerja baik sebagai kuda pacu maupun untuk menarik beban. Kuda pacu sebagai ternak untuk diperlombakan mempunyai keunikan dalam hal mengkonsumsi pakan, sebab tujuan pemberian pakan adalah untuk mencapai prestasi yang baik pada saat pacuan, oleh sebab itu perlu diperhatikan pakan maupun zat-zat makanan yang terkandung dalam pakan.

Manajemen pemeliharaan kuda pacu, termasuk manajmen pemberian pakan di Indonesia sebagian besar masih mengacu pada pemberian pakan yang dilakukan oleh negara-negara maju. Hal ini disebabkan karena kebiasaan secara turun temurun serta faktor gengsi para peternak kuda maka peternak kuda lebih mengandalkan bahan baku pakan impor. Indonesia merupakan negara agraris di mana bahan baku pakan lokal berupa bijibijian dan hijauan cukup tersedia sebagai sumber pakan kuda. Melihat tujuan produksi kuda untuk kemampuan kerja baik saat dipacu maupun menarik beban, serta bentuk atau postur tubuh yang ideal dan tampak indah waktu diperlombakan maka tentunya faktor yang sangat penting diperhatikan adalah pakan, khususnya zatzat makanan.

Kecernaan zat-zat makanan merupakan faktor yang sangat menentukan 
kualitas bahan pakan atau ransum yang dikonsumsi ternak kuda. Kuda termasuk hewan herbivora nonruminan. Dari aspek pencernaan makanan, kuda digolongkan sebagai hewan dengan alat pencernaan perut bagian belakang (hindgut fermentor). Sistem pencernaan ternak kuda berbeda dengan ternak lainnya. Oleh karena itu perlu dilakukan penelitian untuk menguji kecernaan pakan karena tinggi rendahnya kecernaan bahan pakan memberikan arti seberapa besar bahan pakan itu mengandung zat-zat makanan dalam bentuk yang dapat dicernakan ke dalam saluran pencernaan.

\section{MATERI DAN METODE PENELITIAN}

Penelitian ini telah dilaksanakan di desa Tompaso II, Kecamatan Tompaso, Kabupaten Minahasa selama 10 hari terhitung mulai tanggal 27 Oktober sampai dengan tanggal 5 November 2013. Kemudian dilakukan penelitian kembali dikarenakan data yang sebelumnya belum akurat. Penelitian dilaksanakan selama 10 hari terhitung mulai tanggal 30 Maret sampai dengan 8 April 2014.

Alat-alat yang digunakan dalam penelitian yaitu timbangan, kantong plastik dan alat tulis menulis. Untuk bahan-bahan yang digunakan meliputi jenis-jenis bahan pakan hijauan dan konsentrat sesuai dengan yang diberikan oleh peternak kuda pacu di Minahasa. Pakan yang digunakan adalah rumput Australia (Brachiaria mutica), rumput Paspalum sp, tebon jagung, dan pakan konsentrat yang terdiri dari pakan lokal dan impor antaralain; kacang hijau, gabah (Oriza sativa), jagung (Zea mays L.), kedelai (Glycine max), Oat (Avesia sativa), Sustaina. Tabel 1, dan Tabel 2 menampilkan komposisi zat-zat makanan bahan pakan penelitian.

Penelitian ini menggunakan ternak kuda pacu hasil persilangan kuda lokal dengan kuda thoroughbred dari Australia yang mengikuti Seleksi Kejurnas Pordasi sebanyak 30 ekor, umur $2-3$ tahun dengan bobot 217 - $383 \mathrm{~kg}$. Data yang dikumpulkan yakni jenis dan jumlah pakan (hijauan dan konsentrat) yang diberikan pada ternak kuda pacu serta jumlah feses $\left(\right.$ g.ekor $^{-1} \cdot$ hari $^{-1}$ ), kemudian diambil sebanyak 30 sampel. Pengambilan sampel dilakukan pada 15 ekor kuda pacu yang menggunakan pakan lokal dan 15 ekor kuda pacu yang menggunakan pakan impor.

Penelitian ini menggunakan metode survei. Teknik pengambilan data adalah wawancara dan pengamatan langsung pada lokasi-lokasi peternakan kuda pacu. Untuk melihat pengaruh dari perlakuan terhadap variabel yang diamati, data hasil penelitian dianalisis dengan menggunakan uji $\mathrm{t}(\mathrm{t}$ test). 
Tabel 1. Kandungan Nutrisi dari Pakan Hijauan

\begin{tabular}{lccccccc}
\hline \multicolumn{1}{c}{ Jenis Pakan } & $\begin{array}{c}\text { BK } \\
\text { \% }\end{array}$ & $\begin{array}{c}\text { Energi } \\
\text { Mkal }\end{array}$ & $\begin{array}{c}\text { Protein } \\
\text { \% }\end{array}$ & $\begin{array}{c}\text { Lemak } \\
\text { \% }\end{array}$ & $\begin{array}{c}\text { SK } \\
\text { \% }\end{array}$ & $\begin{array}{c}\text { Ca } \\
\text { \% }\end{array}$ & $\begin{array}{c}\text { P } \\
\text { \% }\end{array}$ \\
\hline Rumput Lapang & 87.46 & 3.6 & 8.33 & 1.65 & 34.64 & 0.67 & 0.44 \\
Brachiaria Mutica & 88.42 & 3.5 & 10.41 & 1.98 & 32.09 & 0.77 & 0.53 \\
Tebon Jagung & 89.5 & 3.58 & 6.05 & 1.3 & 36.15 & 0.46 & 0.30 \\
\hline Rataan Hijauan & 88.46 & 3.56 & 8.26 & 1.64 & 34.29 & 0.64 & 0.42 \\
\hline
\end{tabular}

Ket: Hasil Analisis Laboratorium Baristand Industri Manado (2014).

Tabel 2. Kandungan Nutrisi dari Bahan Pakan Lokal dan Impor

\begin{tabular}{|c|c|c|c|c|c|c|c|}
\hline Jenis Pakan & $\begin{array}{c}\text { BK } \\
\%\end{array}$ & $\begin{array}{c}\text { Energi } \\
\text { Mkal }\end{array}$ & $\begin{array}{c}\text { Protein } \\
\%\end{array}$ & $\begin{array}{c}\text { Lemak } \\
\%\end{array}$ & $\begin{array}{c}\text { SK } \\
\%\end{array}$ & $\begin{array}{c}\mathrm{Ca} \\
\%\end{array}$ & $\begin{array}{l}\mathbf{P} \\
\%\end{array}$ \\
\hline Jagung $^{*}$ ) & 87.9 & 3.67 & 10.4 & 4.1 & 2.5 & 0.1 & 2.56 \\
\hline K. Hijau $\left.{ }^{*}\right)$ & 90.0 & 3.51 & 22.2 & 1.2 & 5.0 & 1.25 & 3.2 \\
\hline Kedelai ${ }^{*}$ & 91.0 & 4.42 & 35.9 & 18.1 & 8.0 & 2.27 & 3.85 \\
\hline Gabah $\left.^{*}\right)$ & 86.8 & 3.52 & 8.4 & 1.8 & 9.7 & 0.12 & 2.9 \\
\hline $\left.\mathrm{Oat}^{* *}\right)$ & 90.38 & 3.597 & 8.67 & 6.94 & 7.75 & 0.07 & 0.18 \\
\hline Sustaina $\left.^{* *}\right)$ & 89.04 & 17.26 & 13.26 & 6.84 & 9.04 & 0.48 & 0.17 \\
\hline
\end{tabular}

Ket: $\left.{ }^{*}\right)$ Pakan Lokal

${ }^{*}$ Pakan Impor

Hasil Analisis Laboratorium Baristand Industri Manado (2014).

\section{Tatalaksana Penelitian}

1. Tahap Pendahuluan :

Survei dan pengamatan langsung dilakukan di lokasi peternakan kuda pacu, kemudian dilakukan pengumpulan data atau informasi dari peternak/pemilik ternak kuda dengan wawancara secara langsung di lokasi peternakan Kuda Pacu.

2. Tahap Pra-Koleksi :

7 (tujuh) hari sebelum pengambilan data, dilakukan pengamatan dari pakan yang diberikan untuk memastikan apakah pakan dapat dikonsumsi secara keseluruhan dan tidak tersisa.

3. Tahap Koleksi :

Pengumpulan feses dilakukan mulai pukul 05.30 wita sampai dengan keesokkan harinya pada jam yang sama. Pengambilan sampel feses dilakukan selama 3 hari. Setiap hari sampel feses ditimbang total feses untuk setiap ternak, kemudian diambil sejumlah $\quad 1 \quad \mathrm{~kg}$ untuk kebutuhan analisis. Untuk sampel pakan, diambil sebanyak 500 gram konsentrat dan 500 gram hijauan. 


\section{Analisis Sampel}

Sampel pakan dan sampel feses dibawa di Laboratorium Baristand Industri Manado untuk dianalisis kandungan energi, protein dan mineral kalsium $(\mathrm{Ca})$ dan fosfor $(\mathrm{P})$.

\section{Variabel yang Diamati}

\section{Kecernaan Energi}

2. Kecernaan Protein

3. Kecernaan Mineral Kalsium (Ca) dan Fosfor $(\mathrm{P})$

Kecernaan energi, protein, dan mineral $\mathrm{Ca}$ dan $\mathrm{P}$ dihitung berdasarkan rumus (Banerjee, 1978):

1. Koefisien; cerna semu energi ransum (KCE) dihitung sebagai berikut: $\frac{(\text { Kons. } R \times E B R)-\left(\sum \text { fes } x E B \text { fes }\right)}{(\text { Kons } R \times E B R)} \times 100 \%$

KCE : Koefisien cerna semu energi ransum Konsumsi R : Jumlah ransum yang dikonsumsi $\left(\right.$ g.ekor $^{-1} \cdot$ hari $^{-1}$ )

EB : Energi bruto ransum $\left(\right.$ Kkal.ekor $^{-1} \cdot$ hari $\left.^{-1}\right)$

$\sum$ fes : Jumlah feses yang didefikasi $\left(\right.$ g.ekor $^{-1} \cdot$ hari $\left.^{-1}\right)$ EB feses : Energi bruto feses (Kkal.ekor ${ }^{-1} \cdot$ hari $^{-1}$ )

2. Koefisien cerna semu protein kasar ransum $(\mathrm{KCP})$, yaitu:

$\frac{(\text { Kons. R } x \% \text { prot } R)-\left(\sum \text { fes } x \text { prot fes }\right)}{(\text { Kons } R x \% \text { prot })} \times 100 \%$

KCPr : Koefisien cerna semu protein kasar ransum (\%)

Kons R: Jumlah ransum yang dikonsumsi (g.ekor ${ }^{-1} \cdot$ hari $^{-1}$ )

Prot R : Protein kasar ransum (\%)

$\sum$ fes : Jumlah feses yang didefikasi $\left(\right.$ g.ekor $^{-1} \cdot$ hari $\left.^{-1}\right)$

$\%$ Prot fes : Protein feses (\%)
3. Koefisien cerna Kalsium $(\mathrm{Ca})$ ransum (KCCa) dihitung sebagai berikut:

$\frac{(\text { Kons. } R x \% \text { CaR })-\left(\sum \text { fes } x \% \text { Ca fes }\right)}{(\text { Kons } R \times \% \text { CaR })} \times 100 \%$

$\mathrm{KCCa}$ : Koefisien cerna semu kalsium kasar ransum $(\%)$

Kons $\mathrm{R}$ : Jumlah ransum perlakuan yang dikonsumsi $\left(\right.$ g.ekor ${ }^{-1} \cdot$ hari $\left.^{-1}\right)$

$\mathrm{Ca} \mathrm{R} \quad$ : Kalsium kasar ransum (\%)

$\sum$ fes : Jumlah feses yang didefikasi $\left(\right.$ g.ekor $^{-1} \cdot$ hari $\left.^{-1}\right)$

$\%$ Ca fes : Kalsium (Ca) feses (\%)

4. Koefisien cerna Fosfor (P) ransum (KCP) dihitung sebagai berikut:

$$
\frac{(\text { Kons. R } x \% P R)-\left(\sum \text { fes } x \% P \text { fes }\right)}{(\text { Kons } R \times \% P R)} \times 100 \%
$$

KCP : Koefisien cerna semu Fosfor (P) ransum (\%)

Kons R: Jumlah ransum perlakuan yang dikonsumsi $\left(\right.$ g.ekor $^{-1}$.hari ${ }^{-1}$ )

P R : Fosfor (P) ransum (\%)

$\sum$ feses : Jumlah feses yang didefikasi (g.ekor ${ }^{-1} \cdot$ hari $\left.^{-1}\right)$

$\% \mathrm{P}$ fes : Fosfor $(\mathrm{P})$ feses $(\%)$

\section{HASIL DAN PEMBAHASAN}

Data diperoleh dari 30 ternak kuda pacu Minahasa masing-masing 15 ternak yang mengkonsumsi pakan lokal dan 15 ternak yang mengkonsumsi pakan impor. Nilai rata-rata jumlah konsumsi hijauan dan konsentrat yang diperoleh dapat dilihat pada Tabel 3.

\section{Kecernaan Energi}

Data Tabel 4 menunjukkan, rataan kecernaan energi untuk pakan lokal sebesar $77,774 \%$ dan pakan impor $88,639 \%$. 
Tabel 3. Nilai Rataan Jumlah Konsumsi Kuda Pacu Minahasa dalam Bahan Kering

\begin{tabular}{cccc}
\hline Uraian & Hijauan $(\mathbf{g})$ & Konsentrat $(\mathbf{g})$ & Total Konsumsi (g) \\
\hline Pakan Lokal & 3633 & 7711 & 11344 \\
\hline Pakan Impor & 3659 & 8190 & 11849 \\
\hline
\end{tabular}

Tabel 4. Nilai Rataan Kecernaan dari Kuda Pacu Minahasa yang Mengkonsumsi Pakan Lokal dan Pakan Impor

\begin{tabular}{lcc}
\hline \multicolumn{1}{c}{ Uraian } & Pakan Lokal (\%) & Pakan Impor (\%) \\
\hline Kecernaan Energi & $\pm 77,774^{\mathrm{a}}$ & $\pm 88,639^{\mathrm{b}}$ \\
\hline Kecernaan Protein & $\pm 63,273^{\mathrm{a}}$ & $\pm 72,304^{\mathrm{b}}$ \\
\hline Kecernaan Kalsium $(\mathrm{Ca})$ & $\pm 57,291^{\mathrm{a}}$ & $\pm 67,376^{\mathrm{b}}$ \\
\hline Kecernaan Fosfor $(\mathrm{P})$ & $\pm 61,258^{\mathrm{a}}$ & $\pm 71,903^{\mathrm{b}}$
\end{tabular}

Ket: Nilai pada baris yang sama dengan superskrip yang berbeda menunjukkan pengaruh yang berbeda nyata $(\mathrm{P}<0,05)$.

Hasil uji t, menunjukkan bahwa kecernaan energi pakan impor berbeda nyata lebih tinggi $(\mathrm{P}<0,05)$ dibandingkan dengan kecernaan energi pakan lokal. Berdasarkan hasil uji t, berarti penggunaan pakan impor yang dikonsumsi kuda pacu Minahasa mengandung nilai kecernaan energi yang nyata lebih tinggi dibandingkan dengan pakan lokal.

Meskipun nilai rataan jumlah konsumsi pakan impor lebih tinggi dari pakan lokal namun kandungan energi dari kedua jenis bahan pakan tersebut tidak jauh berbeda. Oleh karena itu untuk melihat potensi kedua jenis pakan tersebut maka perlu melakukan uji tanding untuk membandingkan prestasi yang dicapai antara kuda pacu Minahasa yang diberi pakan lokal dan pakan impor. Tulung (2012) menyatakan bahwa kuda pacu Minahasa yang mengkonsumsi pakan lokal dengan kuda yang mengkonsumsi pakan impor mempunyai prestasi yang hampir sama saat dipacu, yaitu pada jarak tempuh 800 m; 1400 m dan 1600 m; kuda pacu yang diberi pakan impor lebih mengungguli kuda yang diberi pakan lokal dengan selisih waktu 0'.1', sedangkan untuk jarak tempuh $1000 \mathrm{~m}$ dan $1200 \mathrm{~m}$; kuda pacu yang diberi pakan lokal berhasil mengungguli kuda yang diberi pakan impor dengan selisih waktu 0'.1'. Hal ini mungkin disebabkan oleh perbedaan kualitas nilai biologis dari kedua jenis bahan pakan tersebut.

Gibs et al. (2009) mengemukakan bahwa kuda pacu membutuhkan banyak energi untuk mencapai prestasi dan mempertahankan kondisi tubuh optimal saat mengikuti pelatihan dan perlombaan. Menurut Lawrence (2004), kuda menggunakan 80 - 90 persen dari pakan untuk metabolisme energi dengan memanfaatkan karbohidrat dan lemak 
dalam pakan. Lebih lanjut dikatakan bahwa selama mengikuti pelatihan rutin, kuda pacu memanfaatkan pasokan energi dari lemak dalam tubuh. Potter et al. (1990) mengatakan sambil melakukan latihan, kuda mampu mendapatkan cukup oksigen ke jaringan untuk membakar lemak sebagai sumber energi sedangkan selama mengikuti pacuan, kuda tidak dapat mengandalkan sepenuhnya pada lemak tapi kuda memperoleh pasokan energi utama yang tersimpan dalam glukosa darah serta glikogen hati dan otot yang diproduksi dari karbohidrat makanan. Oldham et al. (1990) berpendapat sangat penting untuk diperhatikan bahwa kuda pacu menerima energi yang cukup tersedia dari karbohidrat dalam bahan pakan guna untuk menjaga kadar gula darah dan menyimpan energi dalam bentuk glycogen otot karena ini adalah sumber energi (bahan bakar) utama untuk kuda. Gibs et al. (2009) menambahkan bahwa bahan pakan gandum dan oat menyediakan karbohidrat yang dapat digunakan secara langsung atau disimpan dalam otot dan hati dalam bentuk glikogen untuk digunakan nanti. Secara kuantitas dan kualitas pakan impor memang jauh lebih unggul dibanding pakan lokal.

\section{Kecernaan Protein}

Data Tabel 4 menunjukkan, rataan kecernaan protein untuk pakan lokal sebesar $63,273 \%$ dan pakan impor 72,304\%. Hasil uji t, menunjukkan bahwa kecernaan protein pakan impor berbeda nyata lebih tinggi $(\mathrm{P}<0,05)$ dibandingkan dengan kecernaan protein pakan lokal. Berdasarkan hasil uji t, berarti penggunaan pakan impor yang dikonsumsi kuda pacu Minahasa mengandung nilai kecernaan protein yang nyata lebih tinggi dibandingkan dengan pakan lokal.

Tulung (2012) mengatakan bahwa nilai biologis pakan lokal lebih rendah dibandingkan pakan impor sehingga walaupun tinggi jumlah konsumsi protein, tetapi sedikit yang siap digunakan karena nilai biologisnya rendah. Frape (2004) menyatakan bahwa kandungan protein jagung rendah, walaupun serat kasarnya lebih rendah dari gandum akan tetapi gandum memiliki kualitas yang lengkap untuk kuda pacu. Oleh sebab itu tingkat kecernan protein pakan impor lebih tinggi dibandingkan pakan lokal. Gibs et al., 2002 menambahkan bahwa gandum mengandung (lysine) asam amino yang dianggap esensial bagi ternak kuda, sehingga lebih mudah untuk diserap.

\section{Kecernaan Mineral Kalsium (Ca) dan Fosfor (P)}

Data Tabel 4 menunjukkan, rataan kecernaan mineral $\mathrm{Ca}$ dan $\mathrm{P}$ masingmasing untuk pakan lokal sebesar 
$57,291 \% ; \quad 61,258 \%$ dan $67,376 \%$;

$71.903 \%$ rataan kecernaan mineral Ca dan $\mathrm{P}$ pakan impor. Hasil uji t, menunjukkan bahwa kecernaan mineral kalsium $(\mathrm{Ca})$ dan fosfor $(\mathrm{P})$ pakan impor berbeda nyata lebih tinggi $(\mathrm{P}<0,05)$ dibandingkan dengan kecernaan mineral kalsium $(\mathrm{Ca})$ dan fosfor (P) pakan lokal. Berdasarkan hasil uji t menunjukkan bahwa penggunaan pakan impor yang dikonsumsi kuda pacu Minahasa mengandung nilai kecernaan mineral kalsium $(\mathrm{Ca})$ dan fosfor $(\mathrm{P})$ yang nyata lebih tinggi dibandingkan dengan pakan lokal. Hal ini mungkin disebabkan oleh jumlah konsumsi mineral untuk pakan lokal yang lebih tinggi sehingga mineral tidak dapat dicerna dan diserap sepenuhnya dengan baik. Hal ini dapat dilihat dari kandungan mineral dalam feses kuda yang mengkonsumsi pakan lokal yang lebih tinggi.

Lawrence (2004) mengemukakan bahwa keseimbangan kalsium dan fosfor sangat penting karena kalsium $(\mathrm{Ca})$ dan fosfor (P) adalah mineral makro penting untuk pemeliharaan jaringan tulang, kontraksi otot dan metabolisme energi. Lanjut dikatakan bahwa rasio pemberian kalsium $(\mathrm{Ca})$ dan fosfor $(\mathrm{P})$ adalah $2: 1$, karena jika kandungan fosfor (P) lebih tinggi dari kalsium (Ca) akan mengakibatkan tulang melemah dan terjadi stres pada kuda.

\section{KESIMPULAN}

Berdasarkan hasil penelitian ini dapat disimpulkan bahwa kecernaan energi, protein, dan mineral kalsium $(\mathrm{Ca})$ dan Fosfor (P) untuk pakan impor lebih baik dibandingkan dengan pakan lokal.

\section{SARAN}

Perlu adanya sentuhan teknologi, agar pakan lokal dapat digunakan sebagai pakan utama ternak kuda pacu Indonesia.

\section{DAFTAR PUSTAKA}

Banerjee, 1978. Animal Nutrition. Oxford LBH Publ. Co. Calcutta. Bombay. New Delhi.

Blakely, J dan D. H Bade. 1992. Ilmu Peternakan. Penerjemah B. Srigdanono. Gadjah Mada University Press. Yogyakarta.

Frape, D. 2004. Equine Nutrition and Feeding. Churcill Livingstone Inc. New York.

Gibs, P. G. dan G. D. Potter. 2002. Concepts in Protein Digestion and Amino Acid Requirements of Young Horses. Professional Animal Scientist. 
Gibs, P. G., G. D. Potter dan B. D. Scott. 2009. Feeding Race Prospects and Racehorses in Training. Texas A\&M University Department Of Animal Science Equine Science Program. Edited by Michael Benefield. Edited by Michael Benefield.

Lawrence, L. A. 2004. Feeding The Performance Horse. Washingston State University Extension. Subject Code 160. A

Potter, G. D., S. P. Webb, J. W. Evans dan G. W. Webb. 1990. Digestible energy requirements for work and maintenance of horses fed conventional and fat-supplemented diets. Journal of Equine Veterinary Science. 10(3):214-218.

Oldham, S. L., G. D. Potter, J. W. Evans, S. B. Smith, T. S. Taylor dan W. S. Barnes. 1990. Storage and mobilization of muscle glycogen in exercising horses fed a fatsupplemented diet. Journal of Equine Veterinary Science. 10(5):15.
Oroh, R.K.P. 2004. Determinasi Kebutuhan Energi Untuk Kerja Berdasarkan Jumlah Pakan Yang Dikonsumsi Dalam Bahan Kering, Bobot Metabolik, dan Beban Kerja Kuda Pacu. Skripsi. Jurusan Ilmu Nutrisi dan Makanan Ternak. Fakultas Peternakan - Unsrat. Manado.

Tulung, Y. L. R. 2012. Kebutuhan Energi dan Nutrien Kuda Pacu Indonesia dan Aplikasi pada Formulasi Ransum Berbasis Pakan Lokal. Disertasi. Program Pascasarjana, Institut Pertanian Bogor. Bogor. 